\title{
Virulence factors and antibiotic resistance properties of the Staphylococcus epidermidis strains isolated from hospital infections in Ahvaz, Iran
}

\author{
Roya Chabi and Hassan Momtaz
}

\begin{abstract}
Background: Resistant Staphylococcus epidermidis strains are considered to be one of the major causes of human clinical infections in hospitals. The present investigation was done to study the pattern of antibiotic resistance and the prevalence of virulence and antibiotic resistance genes amongst the S. epidermidis strains isolated from human hospital infections.

Methods: One hundred hospital infectious samples were collected and S. epidermidis strains were identified using culture and biochemical tests. Isolated strains were subjected to disk diffusion and PCR.

Results: Forty-six out of 100 hospital infectious samples (46\%) were positive for S. epidermidis. S. epidermidis strains harbored the highest prevalence of resistance against penicillin (95.65\%), tetracycline (91.30\%), erythromycin (82.60\%), cefazolin (78.26\%), and trimethoprim-sulfamethoxazole (73.91\%). All S. epidermidis strains had resistance against at least three different types of antibiotics, while the prevalence of resistance against more than seven types of antibiotics was 17.39\%. AacA-D (69.56\%), tetK (56.52\%), mecA (45.65\%), msrA (39.13\%), and tetM (39.13\%) were most commonly detected antibiotic resistance genes. The prevalence of vatC (4.34\%), ermA (8.69\%), vatA (8.69\%), vatB (13.04\%), ermC (13.04\%), and linA (10.86\%) were lower than other detected antibiotic resistance genes. ClfA (32.60\%), agrlll (17.39\%), and etB (13.04\%) were the most commonly detected virulence factors.
\end{abstract}

Conclusions: The presence of virulent and multi-drug resistance S. epidermidis strains showed an important public health issue in hospitals.

Keywords: Staphylococcus epidermidis, Antibiotic resistance, Antibiotic resistance genes, Hospital infections, Iran

\section{Background}

Hospital infections are considered as a major issue all around the world. Bacteria have the highest impact on the occurrence of hospital infections [1-7]. Staphylococcus spp. are commensal bacteria of human skin and have been isolated from diverse clinical sources such as urinary tract infections (UTIs), respiratory tract infections (RTIs), wound infections (WIs), soft tissue infections, blood infections, and endocarditis [3, 8-10]. It has been suggested that Staphylococcus epidermidis (S. epidermidis) is one of the most important species of this group.

\footnotetext{
* Correspondence: hamomtaz@yahoo.com; hamomtaz@iaushk.ac.ir Department of Microbiology, Shahrekord Branch, Islamic Azad University, PO. Box: 166, Shahrekord, Iran
}

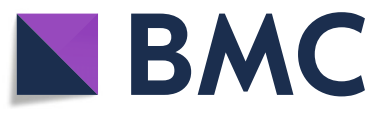

(c) The Author(s). 2019 Open Access This article is distributed under the terms of the Creative Commons Attribution 4.0 International License (http://creativecommons.org/licenses/by/4.0/), which permits unrestricted use, distribution, and reproduction in any medium, provided you give appropriate credit to the original author(s) and the source, provide a link to the Creative Commons license, and indicate if changes were made. The Creative Commons Public Domain Dedication waiver (http://creativecommons.org/publicdomain/zero/1.0/) applies to the data made available in this article, unless otherwise stated.

It is a Gram-positive, non-spore forming, nonmotile, facultative anaerobic, and catalase-positive and coagulasenegative bacterium responsible for different types of hospital and nosocomial infections. Indwelling medical devices are considered a major vector of S. epidermidis in hospitalized patients $[11,12]$. S. epidermidis results in approximately $13 \%$ of prosthetic valve endocarditis infections, with a high rate of intracardiac abscess formation (38\%) and mortality (24\%) [13].

S. epidermidis strains usually resist against several types of antibiotic classes such as tetracyclines, aminoglycosides, cephalosporins, fluoroquinolones, penicillins, and macrolides [14-17]. Nowadays, resistant S. epidermidis has become a serious problem in hospitals [14-16]. Resistant 
staphylococcal strains are responsible for about 100,000 cases of infections with around $10 \%$ mortality rate each year in the USA [16]. The presence of certain antibiotic resistance genes is responsible for the occurrence of antibiotic resistance [14-17]. MecA, aacA-D, tetK and tetM, ermA and $\operatorname{erm} C, m s r A$ and $m s r B$, lin $A$ and vatA, and vatB and vat $C$ antibiotic resistance genes are responsible for the occurrence of resistance against methicillin, aminoglycosides, tetracyclines, macrolide-lincosamide-streptogramin B, macrolides, lincosamides, and streptogramin A groups of antibiotics, respectively $[3,14-17]$ (Table 1 ).

Some potential virulence factors including toxic shock syndrome toxin-1 (TSST-1 encoded by tst), exfoliative toxins A and B (eta and etb), clumping factor (clfA), and types I, II, and III of the accessory gene regulator (agr) are responsible for virulence characters of the $S$. epidermidis strains isolated from human clinical infections [10]. The $X$ region gene of Staphylococcus strains has a high degree of importance in the occurrence of diseases, and it may have a variation rate (or clock speed) that provides suitable discrimination for outbreak investigation [10]. The IgG-binding region is responsible for causing host specificity and various immunological responses against Staphylococcus strains. The X-region and IgG-binding region have been detected in various types of staphylococcal infections [10].

Scarce researches have been conducted on epidemiological and molecular aspects of the S. epidermidis strains in hospital infections in Iran. Thus, the current research was done to study the prevalence rate, distribution of virulence factors, and antimicrobial resistance properties of $S$. epidermidis strains isolated from various types of human clinical infections collected from Ahvaz city, Iran.

\section{Results}

The present investigation was done to assess the antibiotic resistance properties and distribution of virulence genes amongst the S. epidermidis strains isolated from different types of hospital infectious samples. Forty-six out of 100 hospital infectious samples (46\%) were positive for S. epidermidis.
Table 2 represents the antibiotic resistance pattern of the $S$. epidermidis strains isolated from hospital infectious samples. S. epidermidis strains harbored the highest prevalence of resistance against penicillin (95.65\%), tetracycline (91.30\%), erythromycin (82.60\%), cefazolin (78.26\%), and trimethoprim-sulfamethoxazole (73.91\%) antibiotic agents. Reversely, S. epidermidis strains harbored the lowest prevalence of resistance against nitrofurantoin (34.78\%) and mupirocin (50\%) antibiotic agents. The prevalence of resistance against ciprofloxacin, clindamycin, azithromycin, and rifampin antibiotic agents were $69.56 \%, 65.21 \%$, $60.86 \%$, and $60.86 \%$, respectively.

Figure 1 represents the prevalence of multi-drug resistant S. epidermidis strains isolated from hospital infectious samples. Multidrug-resistant $S$. epidermidis strains were determined as those who had at least simultaneous resistance against three or more than three types of antibiotics. All S. epidermidis strains had resistance against at least three different types of antibiotics, while the prevalence of resistance against more than seven types of antibiotics was $17.39 \%$.

Table 3 represents the distribution of antibiotic resistance genes amongst the S. epidermidis strains isolated from hospital infectious samples. We found that aacA-D (69.56\%), tetK (56.52\%), mecA (45.65\%), msrA (39.13\%), and tetM (39.13\%) were most commonly detected antibiotic resistance genes amongst the S. epidermidis strains. The prevalence of vatC $(4.34 \%)$, ermA $(8.69 \%)$, vatA $(8.69 \%)$, vatB (13.04\%), $\operatorname{erm} C(13.04 \%)$, and $\operatorname{lin} A(10.86 \%)$ were lower than other detected antibiotic resistance genes. The prevalence of $m s r A$ and $m s r B$ antibiotic resistance genes were $36.13 \%$ and $26.08 \%$, respectively.

tetK (56.52\%), mecA (45.65\%), msrA (39.13\%), and tet $M(39.13 \%)$ were most commonly detected antibiotic resistance genes. The prevalence of vatC (4.34\%), ermA (8.69\%), vatA (8.69\%), vatB (13.04\%), ermC (13.04\%), and $\operatorname{lin} A(10.86 \%)$ were lower.

Table 4 represents the distribution of virulence factors amongst the $S$. epidermidis strains isolated from hospital infectious samples. We found that clfA (32.60\%), agrIII

Table 1 Antibiotic resistance pattern of the S. epidermidis strains isolated from different types of hospital infectious samples

\begin{tabular}{|c|c|c|c|c|c|c|c|c|c|c|c|}
\hline \multirow{2}{*}{$\begin{array}{l}\text { Samples } \\
\text { (no. } \\
\text { positive } \\
\text { samples for } \\
\text { S. } \\
\text { epidermidis) }\end{array}$} & \multicolumn{11}{|c|}{ Antibiotic resistance pattern (\%) } \\
\hline & $\mathrm{P} 10^{*}$ & Cef & Cip5 & Clin & $\mathrm{Az}$ & Eryt & Mup & Rif & Tet30 & Tri-Sul & N/F300 \\
\hline UTIs (10) & $9(90)$ & $7(70)$ & $5(50)$ & $5(50)$ & $5(50)$ & $8(80)$ & $2(20)$ & $5(50)$ & $8(80)$ & $6(60)$ & $2(20)$ \\
\hline Wls (20) & $19(95)$ & $16(80)$ & $15(75)$ & $13(65)$ & $12(60)$ & $16(80)$ & $11(55)$ & $12(60)$ & $19(95)$ & $15(75)$ & $8(40)$ \\
\hline RTIS (16) & $16(100)$ & $13(81.25)$ & $12(75)$ & $12(75)$ & $11(68.75)$ & $14(87.50)$ & $10(62.50)$ & $11(68.75)$ & $15(93.75)$ & $13(81.25)$ & $6(37.50)$ \\
\hline Total (46) & $44(95.65)$ & $36(78.26)$ & $32(69.56)$ & $30(65.21)$ & $28(60.86)$ & $38(82.60)$ & $23(50)$ & $28(60.86)$ & $42(91.30)$ & $34(73.91)$ & $16(34.78)$ \\
\hline
\end{tabular}

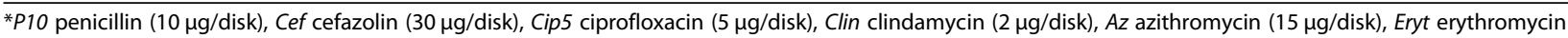
$(15 \mu \mathrm{g} / \mathrm{disk})$, Mup mupirocin $(30 \mu \mathrm{g} / \mathrm{disk})$, Rif rifampin $(5 \mu \mathrm{g} / \mathrm{disk})$, Tet30 tetracycline $(30 \mu \mathrm{g} / \mathrm{disk})$, Tri-Sul trimethoprim-sulfamethoxazole $(25 \mu \mathrm{g} / \mathrm{disk})$, and $\mathrm{N} / \mathrm{F} 300$ nitrofurantoin $(300 \mu \mathrm{g} /$ disk) antibiotic agents 
Table 2 Distribution of antibiotic resistance genes amongst the S. epidermidis strains isolated from different types of hospital infectious samples

\begin{tabular}{|c|c|c|c|c|c|c|c|c|c|c|c|c|}
\hline \multirow{2}{*}{$\begin{array}{l}\text { Samples } \\
\text { (no. positive samples } \\
\text { for S. epidermidis) }\end{array}$} & \multicolumn{12}{|c|}{ Antibiotic resistance genes (\%) } \\
\hline & mecA & $m s r A$ & $m s r B$ & $A a c A-D$ & tetk & tetM & vatA & vatB & $\operatorname{vatC}$ & ermA & ermC & $\operatorname{lin} A$ \\
\hline UTIs (10) & $2(20)$ & $2(20)$ & $1(10)$ & $5(50)$ & $4(40)$ & $2(20)$ & $1(10)$ & $1(10)$ & - & $1(10)$ & $1(10)$ & $1(10)$ \\
\hline WIs (20) & $10(50)$ & $9(45)$ & $7(35)$ & $16(80)$ & $12(60)$ & $8(40)$ & $2(10)$ & $3(15)$ & $1(5)$ & $2(10)$ & $3(15)$ & $3(15)$ \\
\hline RTIS (16) & $9(56.25)$ & $7(43.75)$ & $4(25)$ & $11(68.75)$ & $10(62.50)$ & $8(50)$ & $1(6.25)$ & $2(12.50)$ & $1(6.25)$ & $1(6.25)$ & $2(12.50)$ & $1(6.25)$ \\
\hline Total (46) & $21(45.65)$ & $18(39.13)$ & $12(26.08)$ & $32(69.56)$ & $26(56.52)$ & $18(39.13)$ & $4(8.69)$ & $6(13.04)$ & $2(4.34)$ & $4(8.69)$ & $6(13.04)$ & $5(10.86$ \\
\hline
\end{tabular}

(17.39\%), and etB (13.04\%) were the most commonly detected virulence factors amongst the S. epidermidis strains isolated from hospital infectious samples. Virulence factors for coa, X-region, and IgG-binding region were negative.

\section{Discussion}

S. epidermidis is a common commensal bacterium of the human skin and mucosa. While $S$. epidermidis has long been considered nonpathogenic, it is now recognized as a relevant opportunistic pathogen $[11,12,14]$. Most $S$. epidermidis-related not only are associated with intravascular devices (prosthetic heart valves, shunts, etc.) but also commonly occur in prosthetic joints, catheters, and large wounds. However, recently published data revealed the high prevalence of $S$. epidermidis in the cases of human clinical infections [11, 12, 14]. Additionally, nosocomial $S$. epidermidis isolates were characterized by their pronounced resistance against many commonly used antibiotics [11, 12, 14].

The present study was done to assess the antibiotic resistance pattern and distribution of antibiotic resistance and virulence genes amongst the $S$. epidermidis strains isolated from different types of human clinical infections. Findings showed that $46 \%$ of human clinical infection samples were positive for S. epidermidis strains. Relatively high prevalence of $S$. epidermidis in the human clinical infections of the present study is may be due to the ubiquitous presence of the bacterium in the hospital environment, its ability to biofilm formation, and finally failure to observe sanitary and disinfection principles in hospitals in Ahwaz city, Iran. Because of the ubiquitous prevalence of $S$. epidermidis as a commensal bacterium, it is often difficult for a clinician to decide whether an isolate represents the causative agent of an infection or an unspecific culture contamination.

S. epidermidis strains harbored the highest prevalence of resistance against penicillin, tetracycline, erythromycin, cefazolin, and trimethoprim-sulfamethoxazole antibiotic agents. All S. epidermidis strains had resistance against at least three different types of antibiotics. Unauthorized and illegal prescription of antibiotics is the main reason for the high prevalence of antibiotic resistance. Mohaghegh et al. [18] reported that the prevalence of antibiotic resistance of the $S$. aureus strains against ampicillin, amoxicillin-clavulanic acid, cefepime, ceftazidime, nalidixic acid, and penicillin were

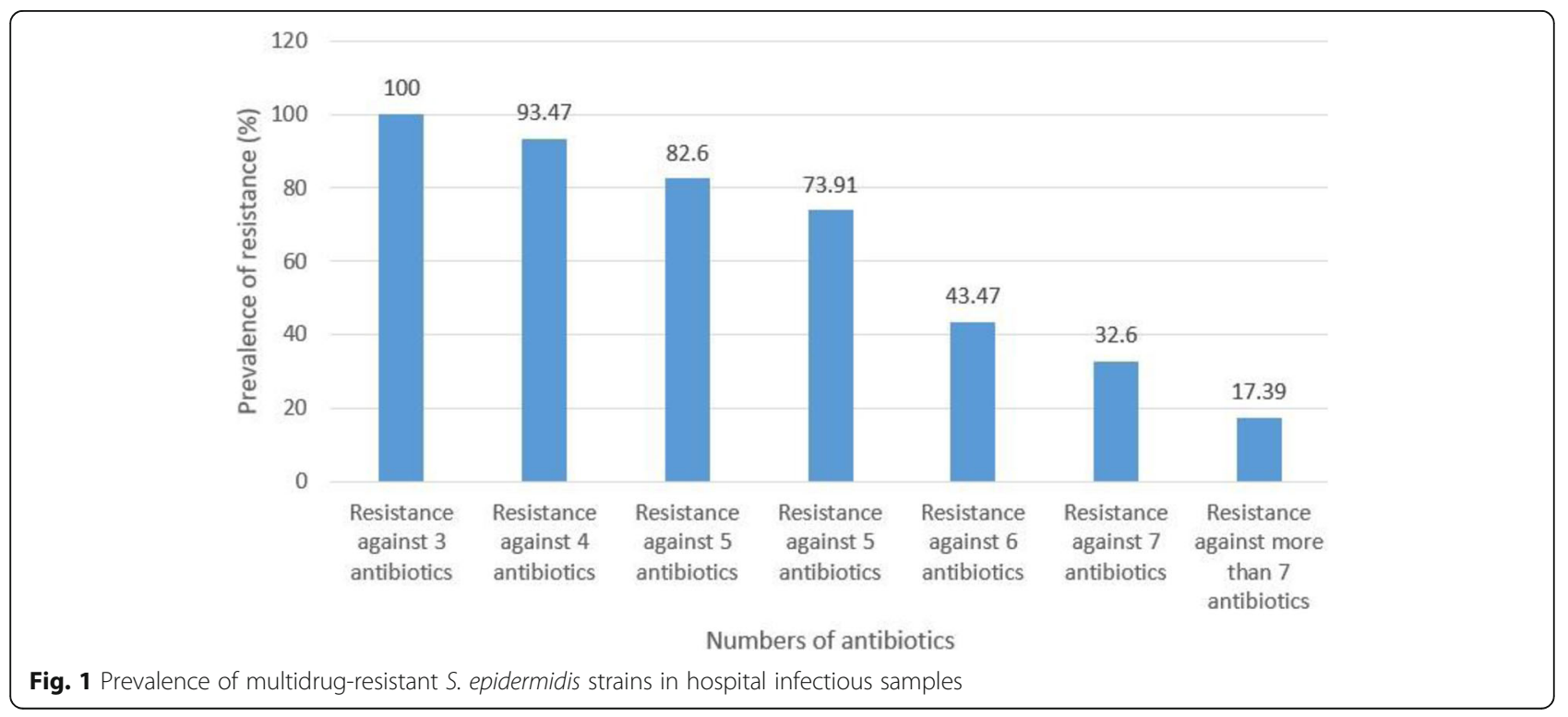


Table 3 Distribution of virulence factors amongst the S. epidermidis strains isolated from different types of hospital infectious samples

\begin{tabular}{|c|c|c|c|c|c|c|c|c|c|c|}
\hline \multirow{2}{*}{$\begin{array}{l}\text { Samples } \\
\text { (no. positive samples } \\
\text { for S. epidermidis) }\end{array}$} & \multicolumn{10}{|c|}{ Virulence factors (\%) } \\
\hline & coa & cIfA & $X$-region & lgG-binding region & tsst-1 & $e t A$ & $e t B$ & agrl & agrll & agrlll \\
\hline UTIs (10) & - & $2(20)$ & - & - & - & - & $1(10)$ & $1(10)$ & $1(10)$ & $2(20)$ \\
\hline Wls (20) & - & $8(40)$ & - & - & $1(5)$ & $2(10)$ & $3(15)$ & $2(10)$ & $2(10)$ & $4(20)$ \\
\hline RTIs (16) & - & $5(31.25)$ & - & - & $1(6.25)$ & $1(6.25)$ & $2(12.50)$ & $1(6.25)$ & $2(12.50)$ & $2(12.50)$ \\
\hline Total (46) & - & $15(32.60)$ & - & - & $2(4.34)$ & $3(6.52)$ & $6(13.04)$ & $4(8.69)$ & $5(10.86)$ & 8 (17.39) \\
\hline
\end{tabular}

$85 \%, 80 \%, 100 \%, 98.30 \%$, 90.90\%, and 90\%, respectively. Moreover, the prevalence of resistance against tetracycline (51\%), erythromycin (41.20\%), oxacillin (97.70\%), cephazolin (58.30), and norfloxacin (51.90\%) was entirely high [18]. Eladli et al. [19] reported that the prevalence of antibiotic resistance of the $S$. epidermidis strains against amoxicillin-clavulanic acid, ciprofloxacin, clindamycin, erythromycin, gentamicin, levofloxacin, mupirocin, oxacillin, rifampin, tetracycline, and trimethoprim-sulfamethoxazole antibiotics was $100 \%$, $100 \%, 37 \%, 0 \%, 33 \%, 16 \%, 0 \%, 80 \%, 0 \%, 80 \%$, and $0 \%$, respectively. Ma et al. [20] reported that the prevalence of antibiotic resistance of the coagulase-negative staphylococci strains against penicillin, oxacillin, erythromycin, tetracycline, clindamycin, ciprofloxacin, trimethoprimsulfamethoxazole, chloramphenicol, ceftizoxime, gentamicin, rifampin, teicoplanin, and vancomycin antibiotics were $94.20 \%, 79.10 \%, 89.50 \%, 59.50 \%, 53.70 \%, 52.80 \%$, $58.50 \%, 39.10 \%, 26.70 \%, 29.50 \%, 18.40 \%, 2.30$, and $0 \%$, respectively. High prevalence of multidrug-resistant S. epidermidis was also reported in their investigation. Similar patterns of antibiotic resistance of the S. epidermidis strains were reported from Mexico [21], Spain [22], Iran [23], USA [24], Belgium [25], and Ireland [26].

S. epidermidis strains isolated from the clinical infection samples harbored the high distribution of antibiotic resistance genes, especially $\operatorname{aac} A-D$, tetK, $\operatorname{mec} A$, and tetM. S. epidermidis strains had a considerable prevalence of resistance against clindamycin (65.21\%). One of the most imperative mechanisms involving resistance against clindamycin is modulated by methylase enzyme which is often encoded by $\operatorname{erm} A$ and $\operatorname{erm} C$ genes [27]. The prevalence of ermA and ermC antibiotic resistance genes amongst the $S$. epidermidis strains of our research were $8.69 \%$ and $10.86 \%$, respectively. The majority of isolates carried two tetracyclines, two erythromycins, one macrolide, and several streptogramin resistance determinants revealed a great diffusion of these types of resistance. The literature-based studies did not indicate any report on the prevalence of vat $A$, vat $B$, vat $C, m s r A$, $\operatorname{erm} A, \operatorname{erm} C, \operatorname{lin} A, \operatorname{aac} A-D, \operatorname{tet} K$, and tet $M$ antibiotic resistance genes amongst the $S$. epidermidis strains isolated from hospital infectious samples. Eksi [28] revealed the higher prevalence of ermA than ermc antibiotic resistance genes amongst the clindamycin, erythromycin, and telithromycin-resistant and also higher prevalence of tet $M$ than tet $K$ antibiotic resistance genes amongst the tetracycline-resistant MRSA strains. Duran et al. [17] reported that the distribution of mecA, femA, ermA, ermB, erm $C$, tet $K$, tet $M, m s r A$, and bla $Z$ antibiotic resistance genes amongst the coagulase negative staphylococci strains isolated from human clinical infections were $29.60 \%, 7.50 \%$, 33.10\%, 5.80\%, 21.60\%, 13.70\%, 28.80\%, $9.40 \%$, and $93.50 \%$, respectively. Adwan et al. [29] reported that the prevalence of $\operatorname{erm} A, \operatorname{erm} C$, tetK, tet $M$, $a a c A-a p h D, v a t A, v a t B$, and vatC genes amongst the staphylococci strains isolated from human infections were $30.90 \%, 74.50 \%, 76.40 \%, 16.40 \%, 74.50 \%, 1.80 \%, 0 \%$, and $5.50 \%$, respectively. High prevalence of tet $K$ and tet $M$ antibiotic resistance genes in the S. epidermidis isolates can be clarified by their usual genetic locations. The presence of tet $K$ gene on small multicopy plasmids and tet $M$ on conjugative transposons contribute to the spread of these determinants [30]. Some of the S. epidermidis strains harbored ermC gene. This gene is often located on small multicopy plasmids which are present in many different staphylococcal species [30]. The ermA gene is usually carried by transposons which could explain its high prevalence amongst the S. epidermidis strains. Resistance to aminoglycosides which are encoded by the $a a c A-D$ gene $(69.59 \%)$ is more prevalent. It is because this gene is usually more diffused in staphylococci of human origin [30].

Amongst all virulence markers found in the S. epidermidis strains, genes encoding clumping factor (clfA), IgG-binding region, toxic shock syndrome toxin (tst), exfoliative toxins (eta and $e t b$ ), accessory gene regulator (agr), and $X$-region were recognized as the most important markers in occurrence of infectious diseases caused by $S$. epidermidis [10]. Eftekhar et al. [31] reported that the frequency of the spa, $f n b B, f n b A, c l f B$, clfA, can, $b b p$, ebp, etb, eta, $p v l$, and tst virulence genes amongst the $S$. aureus strains isolated from hospitalized patients was $100 \%, 75.70 \%, 74.30 \%, 78.60 \%, 71.40 \%$, $24.30 \%, 0 \%, 58.60 \%, 2.90 \%, 7.10 \%, 21.40 \%$, and $51.40 \%$, respectively. Additionally, amongst all the examined 
Table 4 Target genes, oligonucleotide primers, and PCR conditions used for the detection of virulence factors and antibiotic resistance genes in the $S$. epidermidis strains isolated from various types of hospital infectious samples

\begin{tabular}{|c|c|c|c|c|}
\hline Target gene & Primer sequence $\left(5^{\prime}-3^{\prime}\right)$ & PCR product (bp) & PCR programs & PCR volume $(50 \mu \mathrm{L})$ \\
\hline vatA & $\begin{array}{l}\text { F: TGGTCCCGGAACAACATTTAT } \\
\text { R: TCCACCGACAATAGAATAGGG }\end{array}$ & 268 & \multirow{5}{*}{$\begin{array}{l}1 \text { cycle: } \\
94^{\circ} \mathrm{C}, 5 \text { min } \\
30 \text { cycles: } \\
94^{\circ} \mathrm{C}, 60 \mathrm{~s} \\
60^{\circ} \mathrm{C}, 60 \mathrm{~s} \\
72^{\circ} \mathrm{C}, 90 \mathrm{~s} \\
1 \mathrm{cycle:} \\
72^{\circ} \mathrm{C}, 7 \mathrm{~min}\end{array}$} & \multirow{5}{*}{$\begin{array}{l}5 \mu \mathrm{L} \text { PCR buffer } 10 \mathrm{X} \\
1.5 \mathrm{mM} \mathrm{MgCl}_{2} \\
200 \mu \mathrm{M} \text { dNTP (Fermentas) } \\
0.5 \mu \mathrm{M} \text { of each primers } \mathrm{F} \& \mathrm{R} \\
1.25 \cup \text { Taq DNA polymerase (Fermentas) } \\
2.5 \mu \mathrm{L} \text { DNA template }\end{array}$} \\
\hline vatB & $\begin{array}{l}\text { F: GCTGCGAATTCAGTTGTTACA } \\
\text { R: CTGACCAATCCCACCATTITA }\end{array}$ & 136 & & \\
\hline $\operatorname{vatC}$ & $\begin{array}{l}\text { F: AAGGCCCCAATCCAGAAGAA } \\
\text { R: TCAACGTTCTITGTCACAACC }\end{array}$ & 467 & & \\
\hline mecA & $\begin{array}{l}\text { F: AAAATCGATGGTAAAGGTTGGC } \\
\text { R: AGTTCTGCAGTACCGGATTTGC }\end{array}$ & 532 & & \\
\hline tetK & $\begin{array}{l}\text { F: GTAGCGACAATAGGTAATAGT } \\
\text { R: GTAGTGACAATAAACCTCCTA }\end{array}$ & 360 & & \\
\hline tetM & $\begin{array}{l}\text { F: AGTGGAGCGATTACAGAA } \\
\text { R: CATATGTCCTGGCGTGTCTA }\end{array}$ & 158 & \multirow{7}{*}{$\begin{array}{l}1 \text { cycle: } \\
94^{\circ} \mathrm{C}, 5 \text { min } \\
30 \text { cycles: } \\
94^{\circ} \mathrm{C}, 60 \mathrm{~s} \\
60^{\circ} \mathrm{C}, 60 \mathrm{~s} \\
72^{\circ} \mathrm{C}, 90 \mathrm{~s} \\
1 \mathrm{cycle}: \\
72^{\circ} \mathrm{C}, 7\end{array}$} & \multirow{7}{*}{$\begin{array}{l}5 \mu \mathrm{L} \text { PCR buffer 10X } \\
2 \mathrm{mM} \mathrm{MgCl} \\
200 \mu \mathrm{M} \text { dNTP (Fermentas) } \\
0.5 \mu \mathrm{M} \text { of each primers } \mathrm{F} \& \mathrm{R} \\
1.5 \mathrm{U} \text { Taq DNA polymerase (Fermentas) } \\
5 \mu \mathrm{L} \text { DNA template }\end{array}$} \\
\hline msrA & $\begin{array}{l}\text { F: GGCACAATAAGAGTGTTTAAAGG } \\
\text { R: C AAGTTATATCATGAATAGATTGTCCTGTT }\end{array}$ & 940 & & \\
\hline$m s r B$ & $\begin{array}{l}\text { F: TATGATATCCATAATAATTATCCAATC } \\
\text { R: AAGTTATATCATGAATAGATTGTCCTGTT }\end{array}$ & 595 & & \\
\hline$a a c A-D$ & $\begin{array}{l}\text { F: TAATCCAAGAGCAATAAGGGC } \\
\text { R: GCCACACTATCATAACCACTA }\end{array}$ & 227 & & \\
\hline ermA & $\begin{array}{l}\text { F: AAGCGGTAAACCCCTCTGA } \\
\text { R: TTCGCAAATCCCTTCTCAAC }\end{array}$ & 190 & & \\
\hline ermC & $\begin{array}{l}\text { F: AATCGTCAATTCCTGCATGT } \\
\text { R: AATCGTCAATTCCTGCATGT }\end{array}$ & 229 & & \\
\hline $\operatorname{lin} A$ & $\begin{array}{l}\text { F: GGTGGCTGGGGGGTAGATGTATTAACTGG } \\
\text { R: GCTTCTIITGAAATACATGGTATTITCGA }\end{array}$ & 323 & & \\
\hline tsst-1 & $\begin{array}{l}\text { F: ATGGCAGCATCAGCTTGATA } \\
\text { R: TITCCAATAACCACCCGTTT }\end{array}$ & 350 & \multirow{3}{*}{$\begin{array}{l}1 \text { cycle: } \\
94^{\circ} \mathrm{C}, 6 \text { min } \\
30 \text { cycles: } \\
94^{\circ} \mathrm{C}, 2 \text { min } \\
55^{\circ} \mathrm{C}, 2 \text { min } \\
72^{\circ} \mathrm{C}, 1 \text { min } \\
1 \text { cycle: } \\
72^{\circ} \mathrm{C}, 8 \text { min }\end{array}$} & \multirow{3}{*}{ 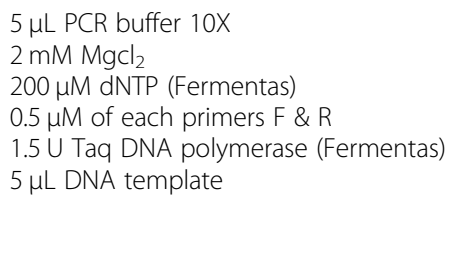 } \\
\hline etA & $\begin{array}{l}\text { F: CTAGTGCATTTGTTATTCAA } \\
\text { R: TGCATTGACACCATAGTACT }\end{array}$ & 119 & & \\
\hline$e t B$ & $\begin{array}{l}\text { F: ACGGCTATATACATTCAATT } \\
\text { R: TCCATCGATAATATACCTAA }\end{array}$ & 200 & & \\
\hline agrl & $\begin{array}{l}\text { F: ATGCACATGGTGCACATGC } \\
\text { R: GTCACAAGTACTATAAGCTGCGAT }\end{array}$ & 441 & \multirow{3}{*}{$\begin{array}{l}1 \text { cycle: } \\
94^{\circ} \mathrm{C}, 6 \text { min } \\
26 \text { cycle: } \\
94^{\circ} \mathrm{C}, 30 \mathrm{~s} \\
55^{\circ} \mathrm{C}, 30 \mathrm{~s} \\
72^{\circ} \mathrm{C}, 1 \mathrm{~min} \\
1 \mathrm{cycle}: \\
72^{\circ} \mathrm{C}, 8 \mathrm{~min}\end{array}$} & \multirow{3}{*}{ 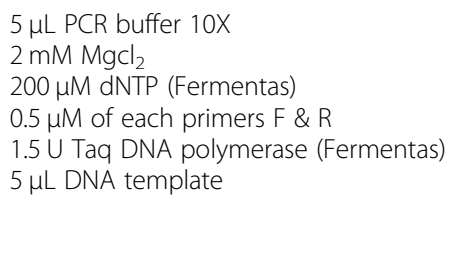 } \\
\hline agrll & $\begin{array}{l}\text { F: ATGCACATGGTGCACATGC } \\
\text { R: TATTACTAATTGAAAAGTGGCCATAGC }\end{array}$ & 575 & & \\
\hline agrlll & $\begin{array}{l}\text { F: ATGCACATGGTGCACATGC } \\
\text { R: GTAATGTAATAGCTTGTATAATAATACCCAG }\end{array}$ & 323 & & \\
\hline coa & $\begin{array}{l}\text { F: CGAGACCAAGATTCAACAAG } \\
\text { R: AAAGAAAACCACTCACATCA }\end{array}$ & 970 & $\begin{array}{l}1 \text { cycle: } \\
95^{\circ} \mathrm{C}, 2 \text { min } \\
30 \text { cycles: } \\
95^{\circ} \mathrm{C}, 30 \mathrm{~s} \\
58^{\circ} \mathrm{C}, 2 \text { min } \\
72^{\circ} \mathrm{C}, 4 \text { min } \\
1 \mathrm{cycle}: \\
72^{\circ} \mathrm{C}, 7 \text { min }\end{array}$ & 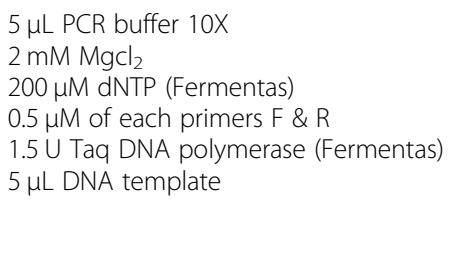 \\
\hline clfA & $\begin{array}{l}\text { F: GGCTTCAGTGCTTGTAGG } \\
\text { R: TITTCAGGGTCAATATAAGC }\end{array}$ & 980 & $\begin{array}{l}1 \text { cycle: } \\
94^{\circ} \mathrm{C}, 4 \text { min } \\
35 \text { cycles: } \\
94^{\circ} \mathrm{C}, 1 \text { min } \\
57^{\circ} \mathrm{C}, 1 \mathrm{~min} \\
72^{\circ} \mathrm{C}, 1 \mathrm{~min} \\
1 \mathrm{cycle}: \\
72^{\circ} \mathrm{C}, 5 \mathrm{~min}\end{array}$ & 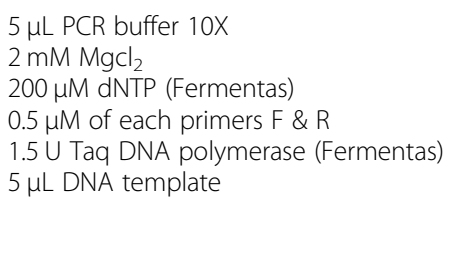 \\
\hline$X$-region & $\begin{array}{l}\text { F: CAAGCACCAAAAGAGGAA } \\
\text { R: CACCAGGTTTAACGACAT }\end{array}$ & 320 & $\begin{array}{l}1 \text { cycle: } \\
95^{\circ} \mathrm{C}, 4 \text { min }\end{array}$ & $\begin{array}{l}5 \mu \mathrm{L} \mathrm{PCR} \text { buffer } 10 \mathrm{X} \\
2 \mathrm{mM} \mathrm{MgCl}_{2}\end{array}$ \\
\hline
\end{tabular}


Table 4 Target genes, oligonucleotide primers, and PCR conditions used for the detection of virulence factors and antibiotic resistance genes in the $S$. epidermidis strains isolated from various types of hospital infectious samples (Continued)

\begin{tabular}{|c|c|c|c|c|}
\hline Target gene & Primer sequence $\left(5^{\prime}-3^{\prime}\right)$ & PCR product (bp) & PCR programs & PCR volume $(50 \mu \mathrm{L})$ \\
\hline & & & $\begin{array}{l}25 \text { cycles: } \\
95^{\circ} \mathrm{C}, 1 \text { min } \\
60^{\circ} \mathrm{C}, 1 \text { min } \\
72^{\circ} \mathrm{C}, 1 \mathrm{~min} \\
1 \mathrm{cycle} \text { : } \\
72^{\circ} \mathrm{C}, 3 \mathrm{~min}\end{array}$ & $\begin{array}{l}200 \mu \mathrm{M} \text { dNTP (Fermentas) } \\
0.5 \mu \mathrm{M} \text { of each primers } \mathrm{F} \& \mathrm{R} \\
1.5 \mathrm{U} \text { Taq DNA polymerase (Fermentas) } \\
5 \mu \mathrm{L} \text { DNA template }\end{array}$ \\
\hline IgG-binding region & $\begin{array}{l}\text { F: CACCTGCTGCAAATGCTGCG } \\
\text { R: GGCTTGTTGTTGTCTTCCTC }\end{array}$ & 920 & $\begin{array}{l}1 \text { cycle: } \\
94^{\circ} \mathrm{C}, 2 \text { min } \\
30 \text { cycles: } \\
94^{\circ} \mathrm{C}, 1 \mathrm{~min} \\
58^{\circ} \mathrm{C}, 1 \mathrm{~min} \\
72^{\circ} \mathrm{C}, 1 \mathrm{~min} \\
1 \mathrm{cycle}: \\
72^{\circ} \mathrm{C}, 5 \mathrm{~min}\end{array}$ & $\begin{array}{l}5 \mu \mathrm{L} \text { PCR buffer } 10 \mathrm{X} \\
2 \mathrm{mM} \mathrm{MgCl} \\
200 \mu \mathrm{M} \text { dNTP (Fermentas) } \\
0.5 \mu \mathrm{M} \text { of each primers } \mathrm{F} \& \mathrm{R} \\
1.5 \cup \text { Taq DNA polymerase (Fermentas) } \\
5 \mu \mathrm{L} \text { DNA template }\end{array}$ \\
\hline
\end{tabular}

genes, clfB (78.60\%) and etb $(2.90 \%)$ had the highest and lowest prevalence, respectively. The prevalence of tsst-1 gene amongst the $S$. epidermidis strains of our research was low (4.34\%). Similar findings have also been reported from Iran (11.60\%) [32], Sweden $(22.00 \%)$ [33], Malaysia (0.50\%) [34], and Colombia (10.00\%) [35]. Tsst-1 gene is a pyrogenic toxin that encodes a 21.9 KDa extracellular toxin causing toxic shock syndrome (TSS). It is known as a severe acute disease distinguished by symptoms such as fever, rash, hypotension, and dysfunction of multiorgan systems. In addition, TSS secretion into the human blood may raise the rate of neonatal TSS-like exanthematous disease, Kawasaki syndrome, and sudden infant death syndrome [32]. Regarding the other detected genes, the eta gene was presented in $6.52 \%$ of strains. The prevalence of $e t b$ gene was $13.04 \%$. The incidence rate of the eta and $e t b$ in the present study was higher than that reported in other investigations conducted on Iran (0.68\%) [32], Colombia (3.00\%) [35], and Malaysia (0\%) [34]. A higher prevalence of eta gene was reported in studies conducted in Czech (10.00\%) [36] and Turkey (19.20\%) [37]. It was detected that the prevalence of the $e t b$ gene differs amongst numerous investigations, ranging from $0 \%$ in Colombia [35] and Malaysia [34] to $9.20 \%$ in Turkey [37]. Ghasemian et al. [38] reported the high prevalence of the clfA and clfB genes (100\%). The incidence of the $c l f A$ gene in the bacterial strains of our research was relatively high $(32.60 \%)$. A higher prevalence of this gene was reported from Brazil [39] and China [40]. Another important detected gene amongst the $S$. epidermidis strains was agr. The prevalence of agrI, agrII, and agrIII virulence genes amongst the S. epidermidis strains were $8.69 \%, 10.86 \%$, and $17.39 \%$, respectively. Agr virulence gene was also predominant amongst the S. epidermidis strains isolated from clinical samples recovered from China [40], USA [41], and Iran [42]. The accessory gene regulator (agr) locus influences the expression of many virulence genes in the S. epidermidis. Four allelic groups of agr, which generally inhibit the regulatory activity of each other, have been identified within the species. Interference in virulence gene expression caused by different agr groups has been suggested to be a mechanism for isolating bacterial populations and a fundamental basis for subdividing the species [43]. It encodes a twocomponent signal transduction system that leads to downregulation of surface proteins and upregulation of secreted proteins during in vitro growth. A role for $a g r$ in virulence has been demonstrated by the attenuated virulence of $a g r$ mutants in different animal infection models [43].

\section{Conclusions}

The present investigation is the first report of the phenotypic and genotypic analysis of antibiotic resistance in the $S$. epidermidis strains isolated from human hospital infectious samples in Iran. The total prevalence of $S$. epidermidis strains in hospital infectious samples was $46 \%$. Considerable prevalence of resistance against penicillin, tetracycline, erythromycin, cefazolin, and trimethoprim-sulfamethoxazole and high distribution of aacA-D, tetK, mecA, and tet $M$ antibiotic resistance genes may pose a potential public health threat. Additionally, clfA, agrIII, and $e t B$ were the most commonly detected virulence factors. A high prevalence of multidrug resistant $S$. epidermidis in the human clinical infectious samples is another important finding of the present study. Moreover, the presence of antibiotic resistance genes and also virulence factors in some S. epidermidis strains should be considered as a serious health hazard. Further researches are required to understand additional epidemiological aspects such as the exact relations between antibiotic resistance genes and virulence factors of the $S$. epidermidis strains in hospital infectious samples. 


\section{Methods}

\section{Samples}

From February to July 2018, a total of 100 various types of hospital infectious samples were randomly collected from several private hospitals of the Ahvaz city, Iran. Hospital infectious samples were defined as those which were collected from hospitalized patients with severe infections such as UTIs, WIs, and RIs. Furthermore, samples were taken from the site of infection. Samples were immediately transferred to the Clinical Microbiology Research Center of the Islamic Azad University of Shahrekord in a cooler with ice packs.

\section{Bacterial isolation}

S. epidermidis was identified by conventional bacteriological tests. The sample was enriched in a tryptic soy broth, and grown on mannitol salt agar, and then catalase, tube coagulase and urease tests, and carbohydrate fermentation were performed. S. epidermidis is catalasepositive, coagulase-negative, urease-positive, unable to ferment D-mannitol and D-trehalose, and able to ferment D-mannose and D-maltose [44, 45].

\section{Antibiotic resistance pattern}

Patterns of antimicrobial resistance of the S. epidermidis strains were studied using the Kirby-Bauer method. A simple disk diffusion technique on the Mueller-Hinton agar (Merck, Germany) medium was used for this purpose. susceptibility of $S$. epidermidis isolates was tested against several types of antibiotic agents including penicillin $(10 \mu \mathrm{g} /$ disk $)$, cefazolin $(30 \mu \mathrm{g} /$ disk $)$, clindamycin $(2 \mu \mathrm{g} /$ disk $)$, mupirocin $(30 \mu \mathrm{g} /$ disk $)$, azithromycin $(15 \mu \mathrm{g} /$ disk), erythromycin $(15 \mu \mathrm{g} /$ disk), tetracycline (30 $\mu \mathrm{g} /$ disk), ciprofloxacin $(5 \mu \mathrm{g} / \mathrm{disk})$, trimethoprim-sulfamethoxazole (25 $\mu \mathrm{g} /$ disk), nitrofurantoin $(300 \mu \mathrm{g} /$ disk), and rifampin (5 $\mu$ g/disk) (Oxoid, UK). The instructions of the Clinical and Laboratory Standards Institute were used for this purpose [46]. The plates containing the disks were allowed to stand for at least $30 \mathrm{~min}$ before incubated at $37^{\circ} \mathrm{C}$ for 24 h. The diameter of the zone of inhibition produced by each antibiotic disc was measured and interpreted using the CLSI zone diameter interpretative standards [46]. S. epidermidis ATCC 12228 was used as a quality control organism in antimicrobial susceptibility determination.

DNA extraction and amplification of virulence factors and antibiotic resistance genes

S. epidermidis isolates were sub-cultured on TSB media (Merck, Germany) and further incubated for $48 \mathrm{~h}$ at $37^{\circ} \mathrm{C}$. Genomic DNA was extracted from bacterial colonies using the DNA extraction kit (Fermentas, Germany) according to the manufacturer's instruction. Table 1 represents the list of primers and PCR conditions used for the amplification of virulence factors and antibiotic resistance genes [47]. A programmable DNA thermo-cycler (Eppendorf Mastercycler 5330, Eppendorf-Nethel-Hinz GmbH, Hamburg, Germany) was used in all PCR reactions.

\section{Statistical analysis}

Statistical analysis was done using the SPSS 21.0 statistical software (SPSS Inc., Chicago, IL, USA). Chi-square test and Fisher's exact two-tailed test were used to assess any significant relationship between the prevalence of $S$. epidermidis strains, virulence factors, and their antibiotic resistance properties. $P$ value $<0.05$ was considered as statistical significant level.

Abbreviation

CLSI: Clinical and Laboratory Standards Institute

\section{Acknowledgements}

The authors would like to thank Dr. Zahra Bamzadeh and Dr. Elaheh Tajbakhsh for their technical assistance.

\section{Authors' contributions}

$\mathrm{HM}$ and RC carried out the molecular genetic studies, participated in the primers sequence alignment, and drafted the manuscript. HM and RC carried out the sampling and culture method, participated in the design of the study, and performed the statistical analysis and writing the manuscript. All authors read and approved the final manuscript.

\section{Funding}

The current research was financially supported by the Islamic Azad University, Shahrekord Branch, Shahrekord (grant number 97/169).

Availability of data and materials

All data analyzed during this study are included in this published article.

Ethics approval and consent to participate

The present study was approved by the Ethical Council of Research of the Faculty of Basic Sciences, Shahrekord Branch, Islamic Azad University, Shahrekord, Iran. Verification of this research project and the licenses related to the sampling process were approved by Prof. Hassan Momtaz (approval ref. number MM 2017/10). Samples were collected from volunteer patients hospitalized in the hospitals. Written informed consents were taken from the participants and their personal information was kept confidential.

\section{Consent for publication}

Not applicable.

\section{Competing interests}

The authors declare that they have no competing interests.

Received: 12 May 2019 Accepted: 26 September 2019

Published online: 05 December 2019

References

1. Ranjbar R, Dehkordi FS, Shahreza MH, Rahimi E. Prevalence, identification of virulence factors, O-serogroups and antibiotic resistance properties of Shigatoxin producing Escherichia coli strains isolated from raw milk and traditional dairy products. Antimicrob Resist Infect Control. 2018;7(1):53.

2. Ranjbar R, Farsani FY, Dehkordi FS. Phenotypic analysis of antibiotic resistance and genotypic study of the vacA, cagA, iceA, oipA and babA genotypes of the Helicobacter pylori strains isolated from raw milk. Antimicrob Resist Infect Control. 2018;7(1):115.

3. Dehkordi FS, Gandomi H, Basti AA, Misaghi A, Rahimi E. Phenotypic and genotypic characterization of antibiotic resistance of methicillin-resistant Staphylococcus aureus isolated from hospital food. Antimicrobial Resistance \& Infection Control. 2017;6(1):104.

4. Ranjbar R, Masoudimanesh M, Dehkordi FS, Jonaidi-Jafari N, Rahimi E. Shiga (Vero)-toxin producing Escherichia coli isolated from the hospital foods; 
virulence factors, o-serogroups and antimicrobial resistance properties. Antimicrob Resist Infect Control. 2017;6(1):4.

5. Hemmatinezhad B, Khamesipour F, Mohammadi M, Safarpoor Dehkordi F, Mashak Z. Microbiological investigation of O-serogroups, virulence factors and antimicrobial resistance properties of Shiga toxin-producing Escherichia coli isolated from ostrich, turkey and quail meats. J Food Saf. 2015;35(4): 491-500.

6. Momtaz H, Safarpoor Dehkordi F, Taktaz T, Rezvani A, Yarali S. Shiga toxinproducing Escherichia coli isolated from bovine mastitic milk: serogroups, virulence factors, and antibiotic resistance properties. Sci World J. 2012;2012: 618709

7. Atapoor S, Dehkordi FS, Rahimi E. Detection of Helicobacter pylori in various types of vegetables and salads. Jundishapur J Microbiol. 2014;7(5):e10013.

8. Dehkordi AH, Khaji L, Shahreza MS, Mashak Z, Dehkordi FS, Safaee Y, Hosseinzadeh A, Alavi I, Ghasemi E, Rabiei-Faradonbeh M. One-year prevalence of antimicrobial susceptibility pattern of methicillin-resistant Staphylococcus aureus recovered from raw meat. Trop Biomed. 2017;34(2): 396-404.

9. Madahi H, Rostami F, Rahimi E, Dehkordi FS. Prevalence of enterotoxigenic Staphylococcus aureus isolated from chicken nugget in Iran. Jundishapur J Microbiol. 2014;7(8):e10237.

10. Momtaz H, Dehkordi FS, Rahimi E, Asgarifar A, Momeni M. Virulence genes and antimicrobial resistance profiles of Staphylococcus aureus isolated from chicken meat in Isfahan province. Iran J Appl Poult Res. 2013;22(4):913-21.

11. Namvar AE, Bastarahang S, Abbasi N, Ghehi GS, Farhadbakhtiarian S, Arezi P, Hosseini M, Baravati SZ, Jokar Z, Chermahin SG. Clinical characteristics of Staphylococcus epidermidis: a systematic review. GMS Hyg Infect Control. 2014;9(3):DOC23.

12. Oliveira WF, Silva PM, Silva RC, Silva GM, Machado G, Coelho LC, Correia MT. Staphylococcus aureus and Staphylococcus epidermidis infections on implants. J Hosp Infect. 2017;98(2):111-7.

13. Chu VH, Miro JM, Hoen B, Cabell CH, Pappas PA, Jones P, Stryjewski ME, Anguera I, Braun S, Munoz P, Commerford P. Coagulase-negative staphylococcal prosthetic valve endocarditis - a contemporary update based on the International Collaboration on Endocarditis: prospective cohort study. Heart. 2009;95(7):570-6.

14. Schaefler S. Staphylococcus epidermidis BV: antibiotic resistance patterns, physiological characteristics, and bacteriophage susceptibility. Appl Microbiol. 1971;22(4):693-9.

15. Cabrera-Contreras R, Morelos-Ramírez R, Galicia-Camacho AN, MeléndezHerrada E. Antibiotic resistance and biofilm production in Staphylococcus epidermidis strains, isolated from a tertiary care hospital in Mexico City. ISRN Microbiol. 2013;2013:918921.

16. Klevens RM, Morrison MA, Nadle J, Petit S, Gershman K, Ray S, Harrison LH, Lynfield R, Dumyati G, Townes JM, Craig AS. Invasive methicillin-resistant Staphylococcus aureus infections in the United States. Jama. 2007;298(15):1763-71.

17. Duran N, Ozer B, Duran GG, Onlen Y, Demir C. Antibiotic resistance genes \& susceptibility patterns in staphylococci. Indian J Med Res. 2012; 135(3):389-96.

18. Mohaghegh MA, Ghazvini K, Jafari R, Alikhani MY, Safari M, Garamjan A, Ali G, Falahi J, Bordbar D. Retrospective study on the prevalence and antibiotic resistance pattern of staphylococcus aureus and staphylococcus epidermidis among patients suspicious of bacteremia during 2006-2011. Int J Enteric Pathog. 2015;3(2):1-5.

19. Eladli MG, Alharbi NS, Khaled JM, Kadaikunnan S, Alobaidi AS, Alyahya SA. Antibiotic-resistant Staphylococcus epidermidis isolated from patients and healthy students comparing with antibiotic-resistant bacteria isolated from pasteurized milk. Saudi J Biol Sci. 2019;26(6):1285-90.

20. Ma XX, Wang EH, Liu Y, Luo EJ. Antibiotic susceptibility of coagulasenegative staphylococci (CoNS): emergence of teicoplanin-non-susceptible CoNS strains with inducible resistance to vancomycin. J Med Microbiol. 2011;60(11):1661-8.

21. Cabrera-Contreras R, Morelos-Ramírez R, Galicia-Camacho AN, MeléndezHerrada E. Antibiotic susceptibility and biofilm production and correlation to methicillin resistant genotype of Staphylococcus epidermidis strains from Mexican hospital. In Proceedings of the 110th General Meeting of the American Society for Microbiology (ASM'10). 2010; 23-27.

22. Delgado S, Arroyo R, Jiménez E, Marín ML, del Campo R, Fernández L, Rodríguez JM. Staphylococcus epidermidis strains isolated from breast milk of women suffering infectious mastitis: potential virulence traits and resistance to antibiotics. BMC Microbiol. 2009;9(1):82
23. Chaleshtori S, Karimi A. Antibiotic resistance pattern of staphylococcus strains isolated from orange and apple juices in Shahre-kord, Iran. Pakistan J Med Sci. 2010;26(3):615-8.

24. Raad I, Alrahwan A, Rolston K. Staphylococcus epidermidis: emerging resistance and need for alternative agents. Rev Infect Dis. 1998;26(5):1182-7.

25. Cherifi S, Byl B, Deplano A, Nagant C, Nonhoff C, Denis O, Hallin M. Genetic characteristics and antimicrobial resistance of Staphylococcus epidermidis isolates from patients with catheter-related bloodstream infections and from colonized healthcare workers in a Belgian hospital. Ann Clin Microbiol Antimicrob. 2014;13(1):20.

26. McManus BA, Coleman DC, Deasy EC, Brennan Gl, O'Connell B, Monecke S, Ehricht R, Leggett B, Leonard N, Shore AC. Comparative genotypes, staphylococcal cassette chromosome mec (SCCmec) genes and antimicrobial resistance amongst Staphylococcus epidermidis and Staphylococcus haemolyticus isolates from infections in humans and companion animals. PLoS One. 2015;10(9):e0138079.

27. Zelazny AM, Ferraro MJ, Glennen A, Hindler JF, Mann LM, Munro S, Murray PR, Reller LB, Tenover FC, Jorgensen JH. Selection of strains for quality assessment of the disk induction method for detection of inducible clindamycin resistance in staphylococci: a CLSI collaborative study. J Clin Microbiol. 2005:43(6):2613-5.

28. Eksi F. Investigation of antibiotic resistance genes and panton-valentine leucocidin in Staphylococcus aureus strains isolated from various clinical samples. Acta Medica Mediterranea. 2017;33(2):341-9.

29. Adwan G, Adwan K, Jarrar N, Amleh A. Molecular detection of nine antibiotic resistance genes in methicillin resistant Staphylococcus aureus isolates. Roman Arch Microbiol Immunol. 2014;73(1-2):9-18.

30. Johler S, Layer F, Stephan R. Comparison of virulence and antibiotic resistance genes of food poisoning outbreak isolates of Staphylococcus aureus with isolates obtained from bovine mastitis milk and pig carcasses. J Food Prot. 2011;74(11):1852-9.

31. Eftekhar F, Rezaee R, Azad M, Azimi H, Goudarzi H, Goudarzi M. Distribution of adhesion and toxin genes in staphylococcus aureus strains recovered from hospitalized patients admitted to the ICU. Arch Pediatr Infect Dis. 2017:5(1):e39349.

32. Alfatemi SM, Motamedifar M, Hadi N, Saraie HS. Analysis of virulence genes among methicillin resistant Staphylococcus aureus (MRSA) strains. Jundishapur J Microbiol. 2014;7(6):e10741.

33. Nowrouzian FL, Dauwalder $\mathrm{O}$, Meugnier $\mathrm{H}$, Bes M, Etienne J, Vandenesch F, Lindberg E, Hesselmar B, Saalman R, Strannegård IL, Åberg N. Adhesin and superantigen genes and the capacity of Staphylococcus aureus to colonize the infantile gut. J Infect Dis. 2011;204(5):714-21.

34. Lim KT, Hanifah YA, Mohd Yusoff MY, Thong KL. Investigation of toxin genes among methicillin resistant Staphylococcus aureus strains isolated from a tertiary hospital in Malaysia. Trop Biomed. 2012;29(2):212-9.

35. Jiménez JN, Ocampo AM, Vanegas JM, Rodríguez EA, Garcés CG, Patiño LA, Ospina S, Correa MM. Characterisation of virulence genes in methicillin susceptible and resistant Staphylococcus aureus isolates from a paediatric population in a university hospital of Medellin, Colombia. Mem Inst Oswaldo Cruz. 2011;106(8):980-5.

36. Sila J, Sauer P, Kolar M. Comparison of the prevalence of genes coding for enterotoxins, exfoliatins, panton-valentine leukocidin and tsst-1 between methicillin-resistant and methicillin-susceptible isolates of Staphylococcus aureus at the university hospital in Olomouc. Biomed Pap Med Fac Univ Palacky Olomouc Czech Repub. 2009;153(3):215-8.

37. Demir C, ASLANTAŞ Ö, Duran N, Ocak S, ÖZER B. Investigation of toxin genes in Staphylococcus aureus strains isolated in Mustafa Kemal University Hospital. Turk J Med Sci. 2011;41(2):343-52.

38. Ghasemian A, Najar Peerayeh S, Bakhshi B, Mirzaee M. Several virulence factors of multidrug-resistant Staphylococcus aureus isolates from hospitalized patients in Tehran. Int J Enteric Pathog. 2015;3(2):1-6.

39. Almeida LM, de Almeida MZ, Mendonça CL, Mamizuka EM. Comparative analysis of agr groups and virulence genes among subclinical and clinical mastitis Staphylococcus aureus isolates from sheep flocks of the northeast of Brazil. Braz J Microbiol. 2013;44(2):493-8.

40. Zhang Y, Xu D, Shi L, Cai R, Li C, Yan H. Association between agr type, virulence factors, biofilm formation and antibiotic resistance of Staphylococcus aureus isolates from pork production. Front Microbiol. 2018;9:1876.

41. Cheung GY, Wang R, Khan BA, Sturdevant DE, Otto M. Role of the accessory gene regulator agr in community-associated methicillin-resistant Staphylococcus aureus pathogenesis. Infect Immun. 2011;79(5):1927-35. 
42. Nasirian S, Saadatmand S, Goudarzi H, Goudarzi M, Azimi H. Molecular investigation of methicillin-resistant Staphylococcus aureus strains recovered from the intensive care unit (ICU) based on toxin, adhesion genes and agr locus type analysis. Arch Clin Infect Dis. 2018;13(2):e14495.

43. Gomes-Fernandes M, Laabei M, Pagan N, Hidalgo J, Molinos S, Hernandez RV, Domínguez-Villanueva D, Jenkins AT, Lacoma A, Prat C. Accessory gene regulator (Agr) functionality in Staphylococcus aureus derived from lower respiratory tract infections. PLoS One. 2017;12(4):e0175552.

44. Tille PM. Bailey \& Scott's Diagnostic Microbiology. 14th edition. London: Mosby; 2018. pp. 254-3.

45. Topley WWC, Wilson GS. Topley \& Wilson Microbiology and Microbial Infection. 10th ed. London: Hodder Arnold; 2005. p. 771-816.

46. CLSI. Performance standards for antimicrobial susceptibility testing; twentyseven informational supplement. CLSI document M100-S26. Wayne: Clinical and Laboratory Standards Institute; 2017.

47. Momtaz H, Hafezi L. Meticillin-resistant Staphylococcus aureus isolated from Iranian hospitals: virulence factors and antibiotic resistance properties. Bosnian J Basic Med Sci. 2014;14(4):219-26.

\section{Publisher's Note}

Springer Nature remains neutral with regard to jurisdictional claims in published maps and institutional affiliations.

Ready to submit your research? Choose BMC and benefit from:

- fast, convenient online submission

- thorough peer review by experienced researchers in your field

- rapid publication on acceptance

- support for research data, including large and complex data types

- gold Open Access which fosters wider collaboration and increased citations

- maximum visibility for your research: over $100 \mathrm{M}$ website views per year

At $\mathrm{BMC}$, research is always in progress.

Learn more biomedcentral.com/submissions 